Article

\title{
Co-Design of a 3D Virtual Campus for Synchronous Distance Teaching Based on Student Satisfaction: Experience at the University of Almería (Spain)
}

\author{
Óscar González-Yebra ${ }^{\circledR}$, Manuel A. Aguilar *®i), Fernando J. Aguilar® and Manuel Lucas \\ Teaching Innovation Group “Eei3D-UAL”, University of Almería. Ctra. de Sacramento s/n 04120, \\ La Cañada de San Urbano, 04120 Almería, Spain; oglezyebra@ual.es (Ó.G.-Y.); faguilar@ual.es (F.J.A.); \\ seddepiel@gmail.com (M.L.) \\ * Correspondence: maguilar@ual.es; Tel.: +34-950-015-997
}

Received: 21 December 2018; Accepted: 17 January 2019; Published: 22 January 2019

\begin{abstract}
This study presents the main advances made in recent years by an innovative teaching group at the University of Almeria, who are attempting to incorporate alternative spaces for teaching-learning interaction. This group is developing a new line of study to obtain the main vectors for creating an accessible 3D virtual campus on the Second Life platform, recognized as a multi-user virtual environment (MUVE). The goal of this work was to measure the satisfaction and perception of a group of university students. To do this, a co-design approach based on student opinions by relating methodological procedures with an adaptation of the Kano model usually used for product design has been followed. The results found by a panel of postgraduate students in the second stage of the educational project, suggest that the synchronous distance teaching proposal developed can effectively facilitate conciliation of family, work and personal life with online teaching-learning. In the case of undergraduate students with class attendance, the use of the $3 \mathrm{D}$ virtual campus is perceived as something more complementary.
\end{abstract}

Keywords: learning environments; 3D virtual campus; Second Life; e-Learning; blended learning; Kano's model; student perception

\section{Introduction}

\subsection{Contextualization}

The line of study described below is the result of several years of work by an innovative teaching group in the framework of the University of Almeria's (UAL) adaptation to the European Higher Education Area of the Bologna process, whose main axis is to study, experiment and evaluate the possibility of incorporating new interaction spaces for Blended Learning and E-Learning. The following question was posed as a starting point: What is the student perception of immersive 3D environments in teaching-learning? Thus, an axis of work was begun which seeks to find out what weaknesses and strengths immersive 3D environments (I3DE) have when they are used as the vehicle for distance teaching-learning (E-Learning and Blended Learning). It is a proposal which seeks to place technology at the service of the people to advance in the real possibility of designing spaces for transfer of knowledge adapted to the new socio-educational reality which society must cope with in a more and more globalized world. In brief, this project pursues exploration of a proposal which can facilitate access by anyone to educational resources.

This line of work concentrates on the university academic situation, where in recent decades, coexistence of different types of education has been promoted to favor the incorporation of the information and communication technologies (ICT) in teaching and learning, especially for distance education because 
they hardly depend on physical spaces. In this change of paradigm, the new technologies are fundamental, since they provide students with the tools and resources for more interactive learning in a much more dynamic atmosphere [1]. The E-learning initiative was strengthened in the framework of the eEurope Global Action Plan in 2001-2004 [2], which attempted to mobilize the main actors in education and training as well as social, industrial and economic stakeholders, for making education the permanent motor of a solidary, harmonious society within the context of a competitive economy. Therefore, the lines which are being worked on in this area are primarily fundamental competencies for today's teaching profession, that is, digital competence [3]. Although there is no single way of understanding educational digital competence, international institutions have tried to establish ICT standards and indicators for education and its initial training [3-5]. One of the best known is the National Educational Technology Standards for Teachers (NETST), developed by the International Society for Technology in Education [6]. In this scenario, a holistic approach was made by Krumsvik [7], who defined this competence on three levels: (i) basic digital skills, the use of basic technological tools for accessing information and communicating in daily situations [8]; (ii) teaching competence with ICT, the use of digital tools along with adequate teaching strategies which facilitate acquisition and construction of knowledge [9]; and (iii) learning strategies, the ability to place the ITCs at the service of their own learning goals, to continue learning, in ever more flexible, self-organizing, cooperative environments [10]. Aware of this reality and committed to seeking continued improvement of educational practice and approach to the public, this line of work enjoyed the collaboration in different stages of an interdisciplinary team made up of professionals in education, design, engineering, and medicine pertaining to different institutions (e.g., University of Almeria, University of Granada, Spanish Society for Intervention in Sexology, etc.) to encourage a line of work which advocates incorporation and implementation of new spaces of interaction for development of distance teaching and learning.

\subsection{D Virtual Immersive Environment (Second Life)}

Of all the existing possibilities based on 3D virtual world generating tools, this work was done with Second Life "SL" [11]. SL is recognized as a multi-user virtual environment (MUVE) [12]. Although it was founded as a company manifestly for profit and with no initial educational vocation, in a short time it became a real milestone in creating virtual spaces [13]. It is a WWW platform based on a computer technology called metaverse (or meta-universe) developed by Linden Lab $^{\circledR}[14]$ and officially launched in June 2003. SL may be defined as a program which generates an interactive three-dimensional virtual reality in which the users create an avatar (graphical representation of the person) to develop a sort of 'parallel life', in which they perform activities in real time. Thus, SL has unique characteristics which suggest its incorporation in teaching practice $[15,16]$, especially in its distance learning modality [17]. It is because of that very soon after it appeared, professors and universities all over the world, mainly English-speaking, began to propose educational uses with this world [18,19]. Allen \& Demchak [20] explain that these 3D virtual environments can be used for the following purposes: virtual presence of institutions, educational processes, training, activity planning, tests, analysis of experiences, experimentation, testing and evaluation, and awareness activities.

During the first decade of the 21st century, in Spain, virtual worlds (islands) were modeled linked to educational institutions, e.g., proposals by some Spanish universities, Carlos III University, Madrid [21] or University of Seville [22]. The formats varied, at the same time that there were only a few, and very little is known about them. In the bibliographic search, around 30 scientific-academic studies were found (practically nonexistent in databases like Web of Science and Scopus) which analyze the introduction of SL in the Spanish university. Of these, the one by Iribas Rudin [23], which compiles cases of SL in education and the presence of Spanish education in this 3D space, should be mentioned.

International scientific literature on SL in general is ample, as reported in Wang and Burton [24], who reviewed over 100 articles in peer-reviewed journals to explore how SL is applied in research and education. However, these publications mostly simply described experiences in the form of comments 
without pre-established research questions and without following any systematic methodology. In their study, Wang \& Burton said the number of publications reached a peak in 2009, and after that began to decline, probably due to the curve new media follow when they come onto the educational scene, at first generating great interest which later diminishes [25].

Very diverse experiments in education have been carried out in SL, for teaching engineering subjects [26] or for developing university student reading skills (college-level developmental reading students) [27]. Beyond academic skills themselves, Parneet [28] proposed using the SL environment for acquiring employability skills from the start of studies. In the end, what was sought with this type of experiments was to advance in an idea of reconceptualization, as suggested by Kim and Blankenship [29], to approach the set of skills an educator in the 21st century digital society requires, in line with the digital competency mentioned in the section above.

Until now, the most of the pilot programmes dealing with SL did not devote enough time to find out what the social perception of the users of these virtual working spaces was. Neither has the level of acceptance and person-3D environment interaction (cognitive ergonomics), or even its use as a 3D simulator of real scenarios for 3D documentation, or worth for nearing historical and/or natural heritage to the public, been scientifically evaluated.

Referring to the usefulness of the I3DE, be noted it allows to several simultaneous students: (i) access to virtual classrooms; (ii) interaction with digital tools; (iii) the identification of the corporeality concept of each student through 'avatars'; (iv) the ability to communicate with the peer group, the faculty and the people who tutor; and (v) the possibility of participating and reproducing experiences similar to those of the real world [30]. Furthermore, in the specific case of SL, it allows the ability to enhance the sense of co-presence of the group of students and immersion in an online environment [31]. Some authors indicate that said virtual presence of the student could reduce some of the pressure students often find themselves under in "face-to-face" teaching [32]. This is partly because representation by an avatar can create an atmosphere more favorable to a certain type of training and creative activity by reducing the lack of initiative and participation in class generated by fear of making a mistake or being judged negatively.

\subsection{Objectives}

The specific objective of this study was to measure the satisfaction and perception of a group of students from Ecuador who were studying for a Master's degree at the University of Almeria with part-time classroom attendance, and who were taking many of their classes in the form of synchronous distance teaching in I3DE (SL Platform). In the framework of a teaching innovation project so-called I3DE-UAL, a comparative analysis was also made between the results of their work (Stage II) and undergraduate results in a previous stage of the project (Stage I).

\section{I3DE-UAL Project Background}

\subsection{Startup Stage}

In the framework of the project, in a first stage of experimentation, a virtual space called the "UAL-SEIS Island" was documented, designed and modeled (see Figure 1). The faculty members in the innovative teaching group were trained in the subject matter for experimental use of this working space in their courses. They were trained in the skills necessary for integrating various technologies in the same virtual classroom, for which they had a WWW navigating screen (browsers), a device for presenting multimedia images (e.g., PowerPoint with Slideshare), interaction among avatars in chats, synchronous voice and gestures, and webinar sessions through the remote UAL classroom [33]. 


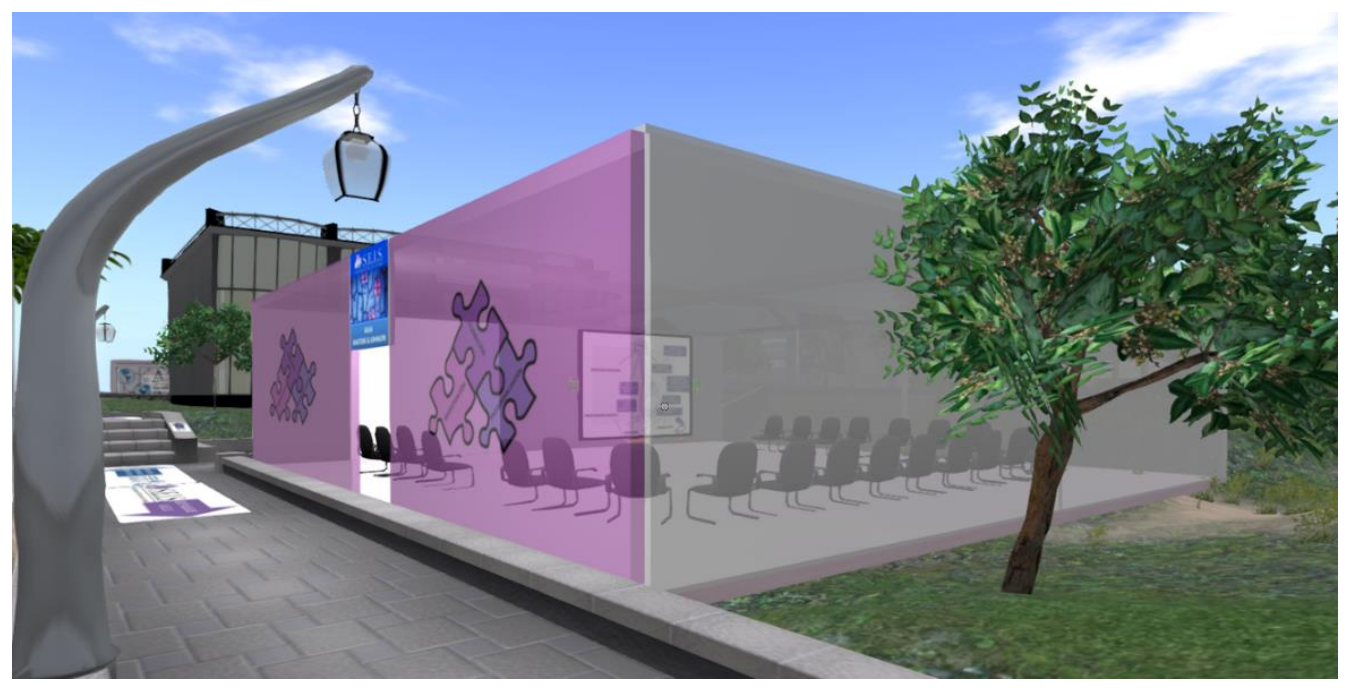

Figure 1. Exterior view of the model of one of the seminar-classrooms in the UAL-SEIS Island, where the first experiences took place.

\subsection{Stage I}

Then in a first stage of the project, an experimental laboratory was developed where a practical teaching seminar was given for the main purpose of exploring the perception of a group of undergraduate students (Mechanical Engineering) of I3DE WWW SL-based teaching. In this case, work was in subjects related to graphic expression in engineering and product development (see Figure 2), specifically, to complement and reinforce classwork in the course on Computer-Assisted Design (CAD). In general, the students valued SL and the UAL-SEIS Island as an effective tool in the context of part-time in-person classes [34]. To date, the UAL-SEIS Island has only been based on a prominently conceptual design, and therefore has not simulated any real space. The two-stage pilot experiments developed also inquired about this (Perception of Graphic Design section).

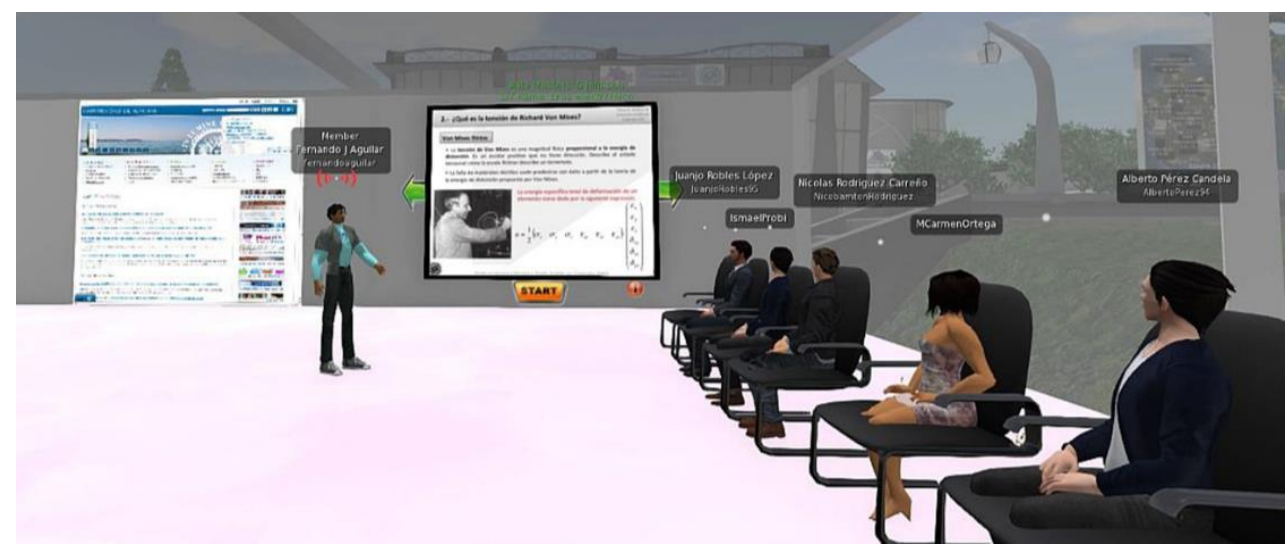

Figure 2. Class of CAD/CAE engineering fundamentals (“working-group" session).

\subsection{Stage II}

The second stage of implementation was carried out with postgraduate students for later comparative analysis between different academic levels and types of teaching-learning. The students who participated in the experiment were studying for an international Master's Degree in "Sexology Sciences" (see Figure 3). The list of items studied in the experiment is shown at the end of this paper based on a series of predefined dimensions ("methodology", "adaptability", "interface", and "proposals") related to the setting and synchronous distance teaching. 


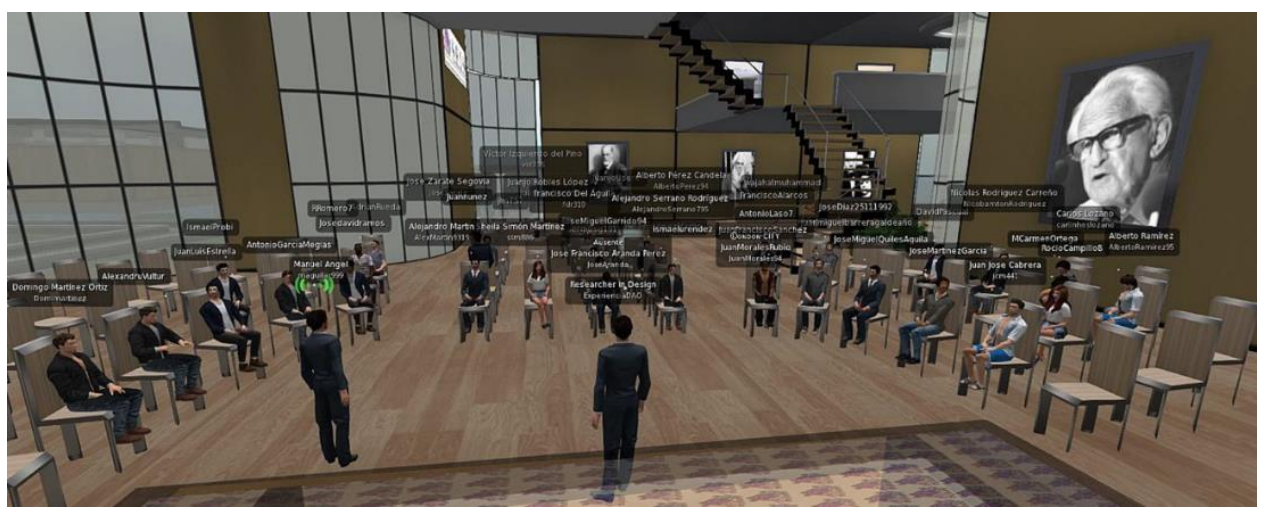

Figure 3. Inaugural conference of the 2016-17 academic years ("teaching-group" session).

\section{Work Methodology}

\subsection{Developing}

Design and planning of the procedure for developing the experimental study was based on a co-design approach (e.g., [35,36]). Co-design is understood as a potential tool for product development [37]. With the co-design approach, for the work team to function properly, it needs to have a common vision of the objective [38], that is, include the client in the design process (in our case the students). An adaptation of the Kano model [39] (see Evaluation Procedure Section), commonly used in industrial design to classify types of quality attributes with different impacts on user satisfaction in order to be able to develop and improve products and/or services, was used for this. A description of each of the Kano model attributes adapted to the context of the present line of work is given below:

- "Attractive" (A): These attributes are the characteristics of the teaching resource which have the most influence on student satisfaction. Attractive attributes are neither expressed explicitly nor expected by the student. Satisfying these attributes leads to more than proportional satisfaction. If they are not found, however, there is no feeling of dissatisfaction.

- "One-dimensional" (O): Student satisfaction with these attributes is proportional to the extent to which they are met. The better they are met, the higher student satisfaction and vice versa. One-dimensional attributes are usually demanded explicitly by the student.

- "Must-be" (M): If these attributes are not satisfied or not met, the student will feel extremely dissatisfied. Furthermore, as students take these attributes for granted, compliance with them will not increase their satisfaction. Must-be attributes are the basic or minimum requirements of the teaching tool or methodology evaluated. Satisfaction with must-be attributes will only lead students to a state of not perceiving dissatisfaction. In effect, the student perceives the must-be attributes as prior requisites and assumes them, so they do not feel the need to explicitly demand them. Must-be attributes are, in any case, a decisive competitive factor. If they are not satisfied, the students probably will not be interested in the resource/methodology.

- "Indifferent" (I): The presence or absence of these does not contribute or increase, nor diminish student satisfaction with the teaching tool evaluated.

- "Reverse" (R): Not only are these characteristics of the teaching resource to be evaluated not desired by students, they even expect the opposite.

- "Questionable" (Q): Usually cause contradictory evaluation, so responses are not generally classified in this category. Responses to questions (functional and dysfunctional) which may be considered questionable show that the question was expressed incorrectly or that the student misunderstood the question or answered incorrectly by mistake.

Table 1 shows the attributes (items) in the line of study asked about, and Table 2 shows an example of how the questions are presented following the Kano model. This section is supplemented 
following the postulates of some researchers who argue that quantitative and qualitative methods complement each other and could bring the research team closer to a better and truer understanding of the object of study. In line with Stockman [40], which looks for the advance in a practical integration of technology in education. Add to this the comments of Gill and Johnson [41], who say there is a growing interest in the use of mixed methodologies which combine quantitative and qualitative approaches either in parallel or sequentially [42]. This type of approach has been described by Teddlie and Tashakkori [43] as a "third" methodological movement with which the pluralism of perspectives is sought. In view of the above, a section was included for other comments and opinions which are usually more spontaneous and open, and with which it was intended to complete the data found with the Kano questionnaires. The questionnaire used was an adaptation of the one used in Stage I [44].

Table 1. Attributes studied in the line of work.

\begin{tabular}{|c|c|c|}
\hline Dimension & Items & Code \\
\hline Methodology & $\begin{array}{l}\text { - Expansion of the training resources offered through Moodle with a three-dimensional } \\
\text { interface type Second Life (SL) } \\
\text { - Complementary interactive activities in SL } \\
\text { - Teaching a theoretical subject matter in SL } \\
\text { - Teaching a practical subject matter in SL } \\
\text { - Development in SL of examples in real time } \\
\text { - Innovation added (from the teaching point of view) to the development of the subject } \\
\text { - SL helps the acquisition more easily of the technical knowledge of the subject } \\
\text { - SL is useful to help reinforce and/or expand your knowledge on the subject } \\
\text { - SL stimulates the development of skills related to creativity }\end{array}$ & $\begin{array}{l}{[\mathrm{M} 1]} \\
{[\mathrm{M} 2]} \\
{[\mathrm{M} 3]} \\
{[\mathrm{M} 4]} \\
{[\mathrm{M} 5]} \\
{[\mathrm{M} 6]} \\
{[\mathrm{M} 7]} \\
{[\mathrm{M} 8]} \\
{[\mathrm{M} 9]}\end{array}$ \\
\hline Interface & $\begin{array}{l}\text { - Easy navigation and exploration to follow a habitual class ( } 1 \mathrm{~h} 30^{\prime} \text { approximately) } \\
\text { - The graphic quality and 3D realism of the Island UAL-SEIS is the current } \\
\text { - Pleasant communication aspect } \\
\text { - Navigation and exploration in SL are in your native tongue } \\
\text { - Good computer equipment and a good internet connection to follow a class normally } \\
\text { - Part of the subject can be followed from home, library, work ... (24 h/24 h) }\end{array}$ & $\begin{array}{l}\text { [I1] } \\
{[\mathrm{I} 2]} \\
{[\mathrm{I} 3]} \\
{[\mathrm{I} 4]} \\
{[\mathrm{I} 5]} \\
{[\mathrm{I} 6]}\end{array}$ \\
\hline Adaptability & $\begin{array}{l}\text { - Increase interest and attention in the development of a subject in general } \\
\text { - Increased interest for the subjects that use the paradigm "learning by doing" (subjects of } \\
\text { high practical content) } \\
\text { - Adaptation to your level of computer knowledge } \\
\text { - Need for a good level of perception and spatial visualization } \\
\text { - It is only advisable for students with a lot of patience }\end{array}$ & $\begin{array}{l}{[\mathrm{A} 1]} \\
{[\mathrm{A} 2]} \\
{[\mathrm{A} 3]} \\
{[\mathrm{A} 4]} \\
{[\mathrm{A} 5]}\end{array}$ \\
\hline Proposals & $\begin{array}{l}\text { - Meetings without teacher assistance, to work in groups specific aspects of the subject } \\
\text { (for example, brainstorming sessions) } \\
\text { - Effort to improve the 3D realism of the Island UAL-SEIS }\end{array}$ & $\begin{array}{l}{[\mathrm{P} 1]} \\
{[\mathrm{P} 2]}\end{array}$ \\
\hline
\end{tabular}

The nature of the project, which is presented as the materialization of a new line of study, first required creation of the I3DE model for the experiment, which was developed in the SL platform. This technology is very similar to what is known as building information modeling (BIM) related to generating and managing data on a building throughout its life cycle using dynamic software and 3D object-oriented modeling of buildings [45]. In this context, BIM technology indexes the relationship of the space by the geometry of its setting, geographic information and properties of the objects (buildings, landscapes, furniture, slide projectors, WWW browsers, etc.). They are true intelligent objects which show the trend in computer graphics virtual reality toward the creation of object-based models (replicable and parametrizable). In the mid-term, the use of the "OpenSimulator" tool is proposed as the server for open code 3D platforms [46].

\subsection{Participants}

The participants (the students taking part in the evaluation of SL in this working line) are divided into two groups, undergraduate participants (Stage I) and postgraduate participants (Stage II). In that sense, 40 students participated at the Stage I [34], while 25 students, took part at the Stage II (this study). Specifically, in this second stage of the project, the proposal was implanted and tested with a group of students from Ecuador who were taking a Master's Degree with part-time classroom attendance, and doing much of their classwork as synchronous distance teaching in I3DE (SL platform). 


\subsection{Evaluation Procedure}

To respond to the objectives set in the project, different methodological procedures were related to the adapted Kano model, generally used for product development and improvement in industrial design. Thus, a feasible proposal could be developed which enabled quantitative estimation of student satisfaction with the proposed environment interface and synchronous distance teaching itself [34]. This second stage attempted to shape the results as graphically as possible by mapping the results. That is, for quantitative analysis of the design and teaching proposal, the following methodological procedures were linked:

1. Classification into Kano attributes - e.g., attractive, one-dimensional, must-be, indifferent, etc. [39] by analyzing the response frequency of student participants (e.g., Table 2), distributed into evaluation groups by the nature of the question, "methodology", "interface", "adaptability", or "proposals".

2. Calculation of the satisfaction coefficient, which is defined by a Satisfaction Index "SI" (Equation (1)) and Dissatisfaction Index "DI" (Equation (2)) [47]. These indices are indicative of the strength with which an attribute can influence satisfaction, or, if not met, student dissatisfaction.

$$
\begin{gathered}
\mathrm{SI}=\frac{\mathrm{A}+\mathrm{O}}{(\mathrm{A}+\mathrm{O}+\mathrm{M}+\mathrm{I})} \\
\mathrm{DI}=\frac{\mathrm{O}+\mathrm{M}}{(\mathrm{A}+\mathrm{O}+\mathrm{M}+\mathrm{I})(-1)}
\end{gathered}
$$

where $\mathrm{A}, \mathrm{O}, \mathrm{M}$, and I represent the number of user responses classified as attractive (A), one-dimensional $(\mathrm{O})$, must-be $(\mathrm{M})$, or indifferent $(\mathrm{I})$.

3. Representation of the results of the two points above on a two-dimensional map for an easy-to-conceive graphical description [48].

\begin{tabular}{|c|c|c|c|}
\hline \multirow{5}{*}{ Functional Question } & \multirow{5}{*}{$\begin{array}{l}\text { If you can follow a part of the subject accessing SL from home, } \\
\text { library, work ... }(24 \mathrm{~h} / 24 \mathrm{~h}) \text {, how do you feel? }\end{array}$} & I like it & $x$ \\
\hline & & I expect it & \\
\hline & & I'm neutral & \\
\hline & & I can tolerate it & \\
\hline & & I dislike it & \\
\hline \multirow{5}{*}{$\begin{array}{l}\text { Dysfunctional } \\
\text { Question }\end{array}$} & \multirow{5}{*}{$\begin{array}{l}\text { If you cannot follow a part of the subject accessing SL from } \\
\text { home, library, work ... ( } 24 \mathrm{~h} / 24 \mathrm{~h}) \text {, how do you feel? }\end{array}$} & I like it & \\
\hline & & I expect it & \\
\hline & & I'm neutral & \\
\hline & & I can tolerate it & $x$ \\
\hline & & I dislike it & \\
\hline
\end{tabular}

Table 2. Sample question according to the Kano model.

\section{Results and Discussion}

\subsection{Survey Population}

With respect to the characterization of the sample, 25 postgraduate students, $28 \%$ were men and $72 \%$ women. By generational groups (digital literacy), 12\% were 'baby boomers' (1940s-50s), 52\% 'Generation X' (1960s-80s), and 36\% 'Millennials' or 'Generation Y' (1980s-90s).

\subsection{Quantitative Evaluation (Student Satisfaction)}

The results of Stage II of the project may be seen in Table 3. It may be observed that six of the nine attributes in the "Methodology" dimension were classified as "Attractive" (A). They may therefore be understood as aspects of the methodology which the student did not expect, and which were very 
positively valued. Bowers, Ragas and Neely [49] noted something similar, suggesting from the role of the professor, that incorporation of SL in their study plans was rather positive and gratifying for the students. In the case of the "interface" dimension, five of six attributes were characterized as "one-dimensional" $(\mathrm{O})$, that is, for example, "that part of the course could be done from different places in the physical classroom: if it is met then it has a high degree of satisfaction, but if not met, a high degree of dissatisfaction is generated". In the "adaptability" dimension, no clear trend was identified. In one case it was "indifferent" (I) (Need for good perception and spatial visualization) and in another case was "reverse" (R) (Only advisable for students with a lot of patience), that is, in this last case, the student expected just the opposite. However, they did value it as something constructive, depending on the degree of compliance, which increases interest and attention during the learning process (Item A1 and A2). These results were directly related to an increase in motivation, as already evaluated by Beltrán Sierra, Gutiérrez, and Garzón-Castro [50] in a study in which they used SL as a supporting element for learning subjects in electronics. In the two improvement proposals suggested, one is classified as "one-dimensional" $(\mathrm{O})$. That is, if the proposal made materialized, it these attributes would have been met, and therefore, student satisfaction would be greater. Taking as a reference studies by other authors [51-53], an increase in student satisfaction will lead to more participation and use of the tool, reducing complaints and increasing individual student performance. Finally, it is important to emphasize that no case was in the "questionable" $(\mathrm{Q})$ category.

Table 3 shows the results of calculating the satisfaction coefficient (SI-DI). This index is indicative of the strength with which one of the attributes studied can influence student satisfaction, or, if not met, dissatisfaction. Although for proper interpretation of the results it should be kept in mind that satisfaction would vary from 0 to 1 . If SI is near 1 , it means that the proposal has a clearly positive effect on increasing student satisfaction. On the other hand, the degree of dissatisfaction would vary from 0 to -1 . If DI is near -1 , it means that the proposal clearly causes student dissatisfaction. It should be mentioned that the satisfaction coefficient could not be determined for Items "P1 and P2" because they were proposals.

Table 3. Quantitative evaluation results.

\begin{tabular}{ccccc}
\hline Dimension & Items & Category & SI & DI \\
\hline \multirow{5}{*}{ Methodology } & M1* & A & 0.88 & -0.40 \\
& M2 & A & 0.80 & -0.40 \\
& M3 & A & 0.88 & -0.29 \\
& M4 & A & 0.64 & -0.27 \\
& M6* & A & 0.88 & -0.25 \\
& M7 & A & 0.92 & -0.36 \\
& M8 & O & 0.88 & -0.72 \\
& M9 & O & 0.80 & -0.64 \\
Interface & I1 & O & 0.92 & -0.56 \\
\hline \multirow{5}{*}{ Adaptability } & I2 & O & 0.79 & -0.52 \\
& I3* & O & 0.96 & -0.63 \\
& I4 & A & 0.96 & -0.43 \\
& I5 & O & 0.78 & -0.48 \\
& I6 & O & 0.96 & -0.68 \\
\hline \multirow{5}{*}{ Proposals } & A1 & O & 0.92 & -0.64 \\
& A2 & O & 0.92 & -0.50 \\
& A4 & O & 0.96 & -0.52 \\
& A5 & I & 0.53 & -0.21 \\
& P1 & R & 0.50 & -0.14 \\
\hline \multirow{5}{*}{} & P2 & O & - & - \\
& O & - & -
\end{tabular}

*Note: Presented partially in an international forum of education and learning [54]. 
A combined analysis of student satisfaction and dissatisfaction should therefore be proposed more than a separate assessment for evaluating each attribute. And so, in this second stage of the project, the results were graphically represented on an overall map, as this enables the attributes which are the most significant from the viewpoint of student satisfaction to be quickly identified. As shown in Figure 4, practically all of the attributes (marked with blue circles) show coherence between the "SI" and "DI" indices, which mean that these characteristics of the teaching method evaluated caused high student satisfaction, placing it in the attractive $(\mathrm{A})$ and one-dimensional $(\mathrm{O})$ quadrants. On the contrary, if it was not met, there would be strong dissatisfaction. With this procedure it can be inferred that these attributes were highly valued by the group of students. This makes it indispensable to include it as a requirement to be considered in developing the teaching resource presented. It should be kept in mind, as noted by Matzler, Hinterhuber, Bailom, and Sauerwein [55], that the long-term purpose is to improve client (student) satisfaction with the product characteristics (I3DE) to establish sustainable competitive advantage, in this case, the training offer and internationalization of other universities.

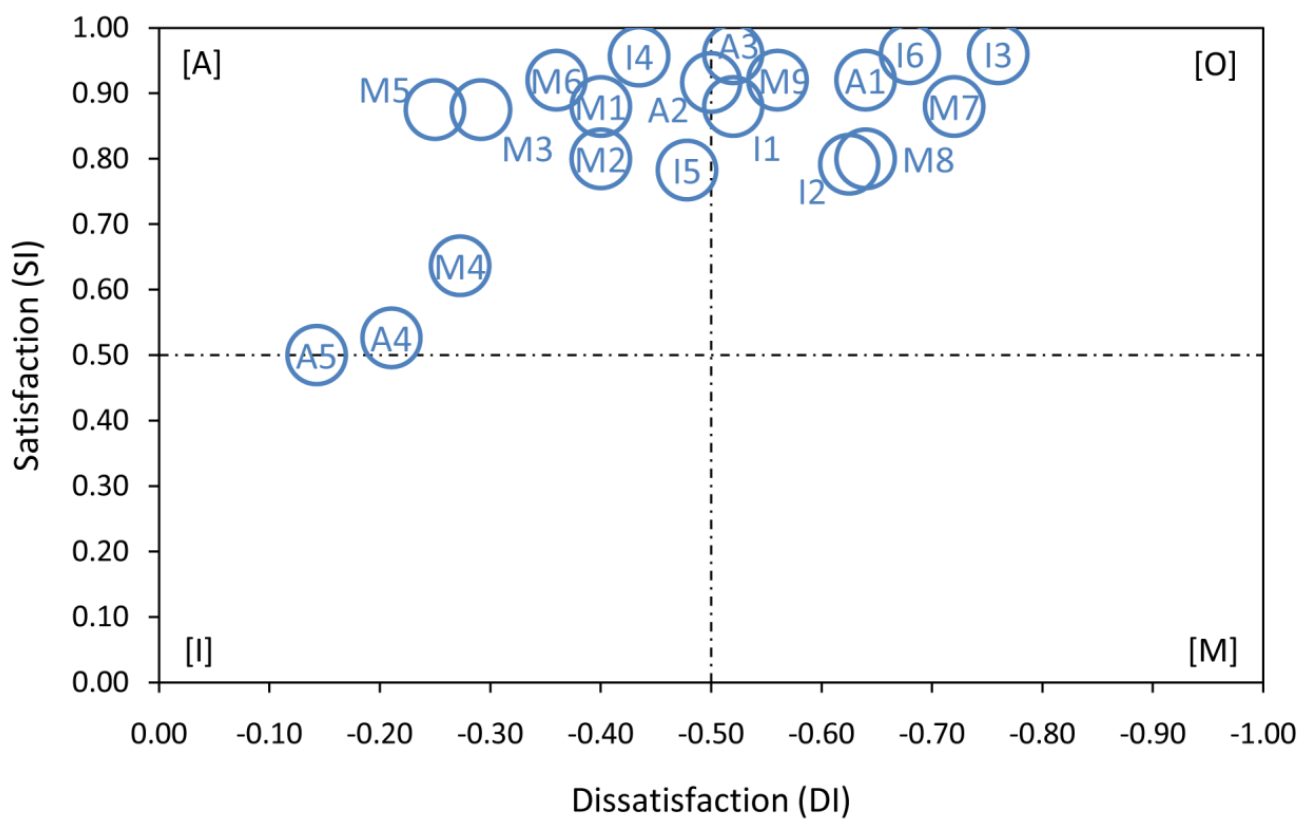

Figure 4. Global map of student satisfaction at the graduate level.

\subsection{Qualitative Evaluation}

The survey instrument included two open questions (Q1 and Q2) to validate and/or compare the quantitative results found from the adapted Kano model developed in the study (quantitative analysis). This section analyses transcriptions of the comments made by the students in these sections, which confirm that the participants valued very positively the plus of innovation in the teaching tool proposed in this project. Some of the contributions of the participating students which had the most impact are given below, including some textual quotations by the students to provide examples of the answers to the questions asked.

\subsubsection{Q1—What Did You Think of the UAL-SEIS Island Training Experience?}

One of the students said, "It is a new alternative distance learning experience due to the physical impossibility of being present in the classes. It is interesting and motivating, a unique experience." This backs the quantitative results. Another comment was, "Very interesting. It made me want to continue studying and facilitated my learning. Excellent pedagogical tool." This type of evaluation places value on the pedagogical reasons pointed out by Dede [56] for exploring virtual worlds like SL. Finally, another of the participants emphasized that, "It is a very useful tool, at the present time when technology has benefited professional preparation and self-improvement (and/or) overcoming 
distances. With SL, education comes to anyone who wishes to continue studying." These comments are in line with one of the benefits emphasized by Pellas and Peroutseas [57]: implementation of courses created in SL goes toward smoothing the 'steep learning curve'. In their case, they used it for introductory high school (pre-university) courses in programming completely extrapolable to higher education. However, it is important not forget that there are studies which warn about digital technology can increase the feeling of isolation, losing the feeling of connection with others, by information overload and distraction [58].

\subsubsection{Q2-Give Some Proposals You Think Would Improve the Experience}

One of the students mentioned, "Take time to try it, not only individually, but as a group, before class time." Another student said, "Improve the 3D reality" (this aspect is analyzed in the section on Perception of Graphic Design). "While the SL experience is positive, my recommendation would be that students have better equipment for it." Similar limitations were reported by Mayrath, Traphagan, Jarmon, Trivedi, and Resta [59] in their study, where many of the students had technical and computer problems.

Summarizing, and taking the opinions given by the students themselves in the two open questions (Q1 and Q2) included in the questionnaire as the basis, students asked for: (i) prior in-person training (in the physical classroom) in the work space, (ii) improved appearance of the 3D campus, that is the UAL-SEIS Island, (iii) familiarization with the settings through more frequent experiences like this, as they think it is a beneficial tool for both students and professors. Finally, an additional limitation to be considered is the need for very good programming that takes into account the time difference between countries when planning synchronous teaching. In general though, the students valued having been able to take their virtual-presence classes with teachers in another country in real time very positively.

\subsection{Comparison of Undergraduate and Postgraduate Experiences}

In a comparison of Stage I with undergraduates [34] and Stage II with postgraduates, significant differences are observed, mostly explained by the experience in Stage I having been carried out with students whose classwork was entirely in-person, while in the second stage, the students were studying part-time in person, but with a high percentage of their time completely at distance. In the first case, they saw the tool as an innovative complement for occasional activities outside of classroom attendance or as a means of widening their knowledge in the subject. In the second case, inclusion of this proposal was intrinsic to the education they were receiving. Nevertheless, in both cases, they took it as a constructive initiative which enabled them to experience less directed and more participatory learning. This demonstrated a high degree of satisfaction with use of SL as a teaching-learning resource, similar to what was reported by Mayrath et al. [59] and Cheng [60]. In a breakdown by item, Figures 5 and 6 show how the items related to the methodological dimension moved toward the top and to the right in Stage II (Figure 4), gaining in prominence. One example of this can be observed in Item "M5", which poses real time development of examples in SL. In Stage I (Figure 5), where they are already developing the examples in person, this evaluation is obviously lower. However, in distance education, this item gains in importance. It should also be added that in the first stage, the course where it was experienced was eminently practical (CAD-CAE Design). However, in both cases this attribute is located in the first quadrant [A], related to an attractive feeling which causes unexpected satisfaction in the student. With respect to the interface, the distribution is more variable. However, a pleasant appearance of communication in the virtual campus (Item I3) was evaluated in both cases as "one-dimensional" $(\mathrm{O})$, where student satisfaction is proportional to the level of compliance. It is striking that having good spatial perception (Item A4) was generally considered indifferent (neutral) in Stage I, possibly because the students were taking a continuation course in fundamentals of graphic expression (including competence in spatial views). This was not the case in Stage II, as the students were in the health sciences. In the "adaptability" dimension, there was again displacement toward the top, but less prominently so. For example, Item A2 increased interest in subjects that use the "learning 
by doing" paradigm, was very highly valued as attractive in both cases, in Stage I as very attractive, and in Stage II attractive to the extent of its compliance. In general though, it may be surmised from experience to date (academic years 2015-16 and 2016-17) that student support for SL as a useful vehicle in teaching-learning was generalized. In line with Mayrath et al. [59], the results reported are based on empirical data and observations, so they are still the perceptions of a few groups of students.

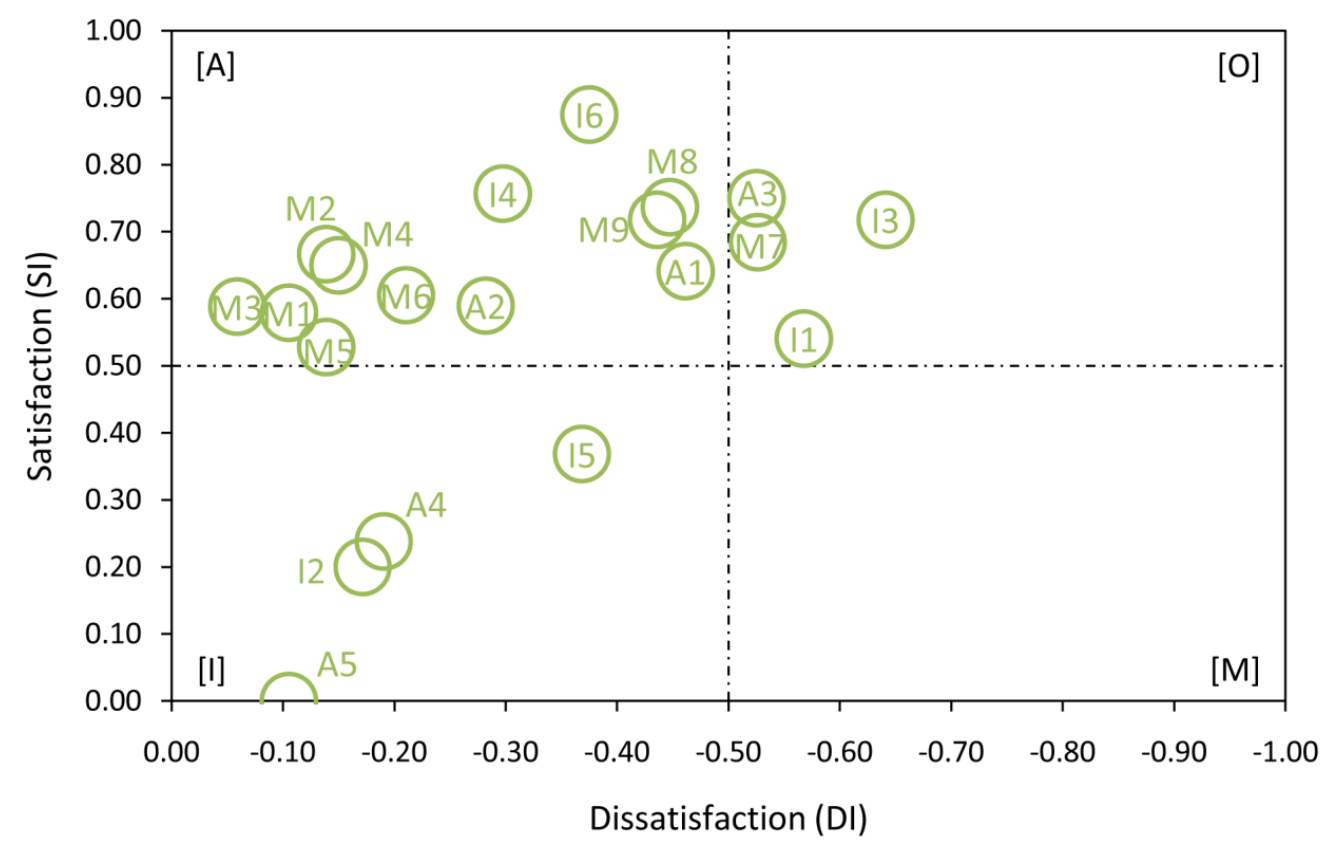

Figure 5. Global map of student satisfaction at grade level (adapted from the results of authors [34]).

\subsection{Perception of Graphic Design}

The results from the two stages of the project with regard to improving the UAL-SEIS Island graphic design (3D realism), showed that both undergraduates, 40 participants, and postgraduates, 25 participants, 74\% (Figure 6) and 92\% (Figure 7) respectively, thought it provided greater satisfaction (unexpected) or proportional to the extent of compliance (classification as "attractive" and "one-dimensional"). This would help to progress in improving the synchronous teaching method proposed.
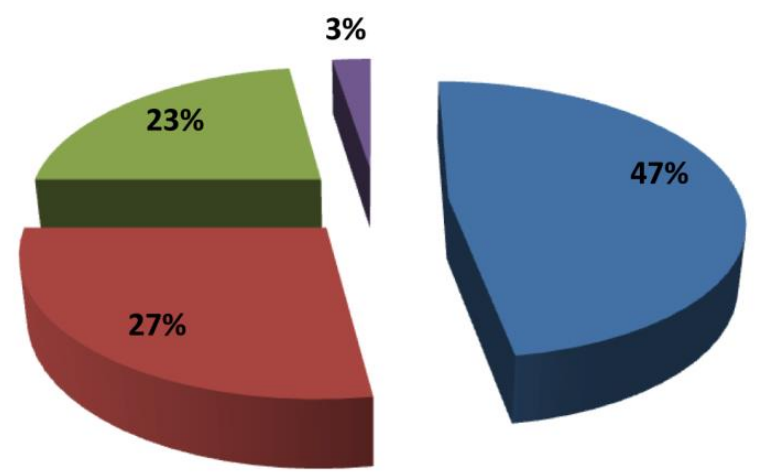

\section{Attractive $\square$ One-dimensional $\square$ Indifferent $\square$ Must-be $\square$ Reverse $\square$ Questionable}

Figure 6. Results of consultations students about the improvement of 3D design (grade level, Stage I).

Thus, a line of 3D digital documentation (see Figure 8) has been started up to really explore and evaluate immersion and interaction in the virtual setting, employing simulated real scenarios to be able 
to give high-quality classes over the WWW or as the means of transmission of contents (for example, historical and natural heritage of Spain). In this case the subject would be taught by a person highly qualified in the subject matter and with virtual presence in the UAL-SEIS Island as a guide avatar.
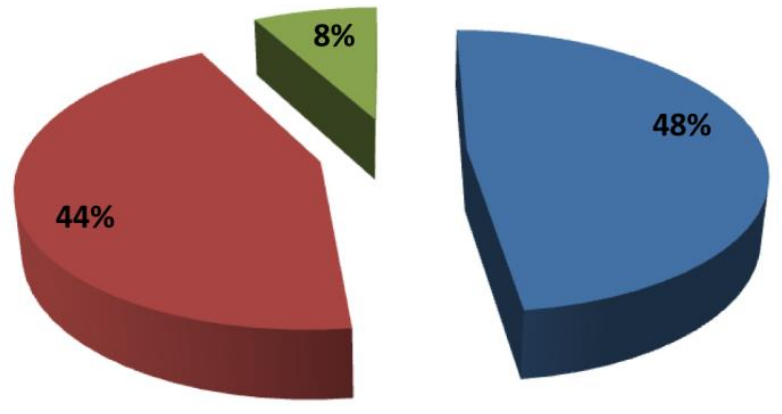

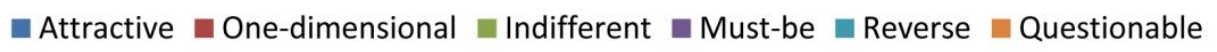

Figure 7. Results of consultations students about the improvement of 3D design (graduate level, Stage II).

\section{Conclusions}

\subsection{Final Analysis}

This paper described the current stage and main milestones in recent years in the line of action, working on analyzing and developing a teaching tool based on I3DE, for synchronous E-Learning and Blended Learning teaching as a teaching resource with practical applications. To date, experiments have taken place in a virtual space which was expressly designed conceptually and located on the SL platform, "UAL-SEIS Island". It was observed a priori in the virtual undergraduate (engineering and architecture) and Master's degree (health sciences) classes and seminars given for several academic years (2015-16/2016-17) that this proposal stimulates student motivation when they become involved for the first time, regardless of the area of knowledge or academic level, mainly because of the plus of innovation which the participating agents emphasized in their evaluations. In the first stage, the students perceived it as a complementary tool (since they were taking all their courses in person), but for the postgraduate students, it was a tool adding constructively to their course, which they were taking only part-time in-person and with a significant part taught exclusively online.

From a comparative perspective, the proposal of a hybrid model which combines synchronous E-learning through I3DE has several advantages over the traditional model of 'face-to-face' teaching, such as: (i) substantially decreasing the cost of teaching staff related to allowances and travel to the (physical) school; (ii) empowering attendance by eliminating physical and/or geographic barriers (avoiding exclusion of rural areas), favoring inclusion and avoiding exclusive digital fracture; (iii) increasing creative possibilities and active participation; (iv) lowering the cost of implantation, and finally; (v) enabling conciliation of family, employment, and personal life.

As a final conclusion, and unlike the more traditional concept of E-learning methodologies, this technological resource would enable the course of study to be given through an effective, agile alternative for distance teaching-learning on the WWW, maintaining, insofar as possible, the feeling of belonging to a class with all of its members, which is an especially important aspect given the visual culture of contact with other people. If this type of tool can be implanted in a regulated and systematic manner in E-learning and blended learning education, it would of interest to find out whether the motivation and innovation which was valued so highly by the students is maintained over time, intending to advance toward a longitudinal evaluation. Due to all of the above, new research questions arise, such as: Do the vectors necessary for true performance of 3D virtual settings in education and 
transfer of knowledge continue beyond the novelty they may awaken in anyone who discovers them for the first time?

\subsection{Limitations}

Concerning the population surveyed consisted of 25 students (average at this academic level), although the statistical significance of the classification of each item evaluated was not our objective, the size of the sample allowed to identify the main attributes pointed out by the students as needed to be included in the design of a learning environment (UAL-SEIS Island).

With regard to technical development, many students expressed problems related to computer limitations. In addition, teaching in the I3DE requires a very good programming that takes into account the time difference, when students from different countries participate, to be able to plan the synchronous teaching.

\subsection{Future Lines of Work}

\subsubsection{In Practical Applications}

In the scope of pre-university education, and as a proposal for the university approaching future undergraduate students, a series of informative sessions could be developed in pilot IEES centers for internal promotion of the use of this tool. In a recent study in which a panel of experts was queried on the role of agro-food industrial design in the Region of Andalusia (Spain) [61], a possible line of action in education developing proposals of the type presented in this paper was suggested to encourage teaching-learning of design in undergraduate and postgraduate degrees in the agro-food sector.

\subsubsection{In Graphic Design}

For the purpose of progressing from a conceptual model to a real world simulation model, work was begun on the design of a new work space. Thus work will be on the design of the real-scale virtual work spaces. In that regard, graphic engineering techniques will be used for the digitization, reconstruction and 3D modeling (terrestrial laser scanner and 3D stereo-photogrammetry from drones) to capture, simplify and introduce the CAD 3D model of the buildings (used as teaching scenarios) in the SL virtual world using the COLLADA (COLLAborative Design Activity) format. Afterwards, evaluation will continue with the adapted Kano model developed in this study. It is intended to analyze the possible differences in student perception after the graphics are improved (cognitive ergonomics), compared to the previous evaluation. Finally, in the mid-term, it is intended to include Kansei engineering in the evaluation process to find out the sensitive-emotional dimension with respect to the teaching resource, that is, include emotional design postulates in the analysis $[62,63]$.

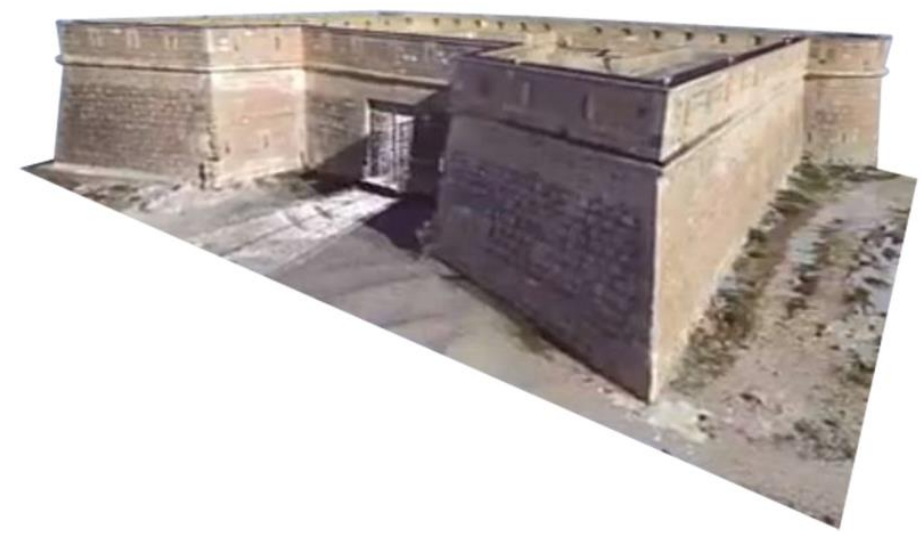

Figure 8. 3D design San Felipe Castle (at Los Escullos, Nijar, Spain) for inclusion in SL. 
Author Contributions: Ó.G.-Y. prepared work methodology, the surveys and collected the input data and, additionally collaborating in manuscript writing and revision. M.A.A. collaborated in the methodology and contributed in manuscript writing and revision. F.J.A. made significant contributions to the research design and manuscript preparation, providing suggestions for the methodology design. M.L. carried out the preparation of the conceptual version of Second Life Island.

Acknowledgments: The development of this work has been possible thanks to a FPI predoctoral grant (first author) of the Research Program of the University of Almeria, and to the support provided by the 2017-2018 University of Almería call for Innovation Teachers' Groups. Many thanks to the teachers who have participated in this phase of the project, and especially to the students who have participated in the different virtual sessions, for their good disposition and their time.

Conflicts of Interest: The authors declare no conflict of interest.

\section{References}

1. Imbernón, F.; Silva, P.; Guzmán, C. Competencias en los procesos de ensenanza-aprendizaje virtual y semipresencial. [Teaching Skills in Virtual and Blended Learning Environments]. Comunicar 2011, 36, 107-114. [CrossRef]

2. European Commission. Communication from the Commission of 28 March 2001: The eLearning Action Plan, Designing Tomorrow's Education. 2001. Available online: http:/ / eur-lex.europa.eu/legal-content/ ES/TXT/?uri=URISERV\%3Ac11050 (accessed on 17 July 2018).

3. UNESCO. ICT Competency Standards for Teachers. Policy Framework; UNESCO: Paris, France, 2008; Available online: http:/ / unesdoc.unesco.org/images/0015/001562/156210E.pdf (accessed on 28 July 2018).

4. Silva Quiroz, J.E. Estándares TIC para la Formación Inicial Docente: Una política pública en el contexto chileno. [ICT Standards for Initial Teacher Training: A public policy in the Chilean context]. Arch. Analíticos Políticas Educ. 2012, 20, 1068-2341.

5. Fraser, J.; Atkins, L.; Richard, H. DigiLit leicester. In Supporting Teachers, Promoting Digital Literacy, Transforming Learning; Leicester City Council: Leicester, UK, 2013.

6. ISTE. National Educational Technology Standards for Teachers; International Society for Technology in Education: Washington, DC, USA, 2009.

7. Krumsvik, R.J. Teacher educators' digital competence. Scand. J. Educ. Res. 2014, 58, 269-280. [CrossRef]

8. Ferrari, A. Digital Competence in Practice: An Analysis of Frameworks; European Commission, Joint Research Centre (JRC): Sevilla, Spain, 2012; Available online: http:/ /ftp.jrc.es/EURdoc/JRC68116.pdf (accessed on 5 August 2018).

9. Mishra, P.; Koehler, M.J.; Henriksen, D. The seven trans-disciplinary habits of mind: Extending the TPACK framework towards 21st century learning. Educ. Technol. 2011, 51, 22-28.

10. Castañeda, L.; Adell, J. (Eds.) Entornos Personales de Aprendizaje: Claves Para el Ecosistema Educativo en Red. [Personal Learning Environments: Keys to the Online Educational Ecosystem]; Marfil: Alcoy, Spain, 2013.

11. Official Site Second Life. Available online: https:/ / secondlife.com (accessed on 17 January 2019).

12. Clarke, J.; Dede, C.; Ketelhut, D.J.; Nelson, B. A design-based research strategy to promote scalability for educational innovations. Educ. Technol. 2006, 46, 27-36.

13. Senges, M.; Praus, T.; Bihr, P. Virtual Worlds. A Second Life Beginner's Guide UOC Summer University Course. 2007. Available online: https://florida.theorangegrove.org/og/file/52ac65c1-0c7f-daba-4d84fc87d07408f1/1/second_life.pdf (accessed on 10 August 2018).

14. Cheong, D. The effects of practice teaching sessions in Second Life on the change in pre-service teachers' teaching efficacy. Comput. Educ. 2010, 55, 868-880. [CrossRef]

15. Linden Lab: Create Virtual Experiences. Available online: https://www.lindenlab.com (accessed on 17 January 2019).

16. Hinrichs, R.; Hill, V.; Patterson, D. Book review: Higher education in Virtual Worlds: Teaching and Learning in Second Life. Inf. Process. Manag. 2011, 47, 143-146. [CrossRef]

17. Burgess, M.L.; Slate, J.R.; Rojas-LeBouef, A.; LaPrairie, K. Teaching and Learning in «Second Life»: Using the Community of Inquiry (CoI) Model to Support Online Instruction with Graduate Students in Instructional Technology. Int. High Educ. 2010, 13, 84-88. [CrossRef]

18. Kamel Boulos, M.N.; Hetherington, L.; Wheeler, S. Second Life: An overview of the potencial of 3D virtual worlds in medical and health education. Health Inf. Libr. J. 2007, 24, 233-245. [CrossRef] [PubMed] 
19. Calongne, C.M. Educational Frontiers: Learning in a Virtual World. Educ. Rev. 2008, 43, 36-48.

20. Allen, P.D.; Demchak, C.C. Applied virtual environments: Applications of virtual environments to government, military and business organizations. J. Virtual Worlds Res. 2011, 4. [CrossRef]

21. López-Hernández, F. El campus de la Universidad Carlos III en Second Life. [The campus of Carlos III University in Second Life]. Prof. Inf. 2008, 17, 657-661. [CrossRef]

22. Del Valle Carreras-Álvarez, M. La docencia virtual en la Universidad de Sevilla: Descripción de las herramientas online. [Virtual Teaching at the University of Seville: Description of online tools]. Hist. Y Comun. Soc. 2013, 18, 49-60.

23. Iribas Rudín, A.E. Enseñanza virtual en Second Life: Una opción online animada para las universidades y las artes. [Virtual teaching in Second Life: An animated online option for universities and the arts]. In IV Jornada Campus Virtual UCM: Experiencias en el Campus Virtual (Resultados); Editorial Complutense: Madrid, Spain, 2008; pp. 125-142, ISBN 978-84-7491-905-9.

24. Wang, F.; Burton, J.K. Second Life in education: A review of publications from its launch to 2011. Br. J. Educ. Technol. 2013, 44, 357-371. [CrossRef]

25. Reiser, R.A. A history of instructional design and technology: Part I: A history of instructional media. Educ. Technol. Res. Dev. 2001, 49, 53-64. [CrossRef]

26. Garzón, C.L.; Beltrán, L.M.; Martínez, P. Estudio de percepción sobre metodologías de enseñanza de temas de electrónica en programas diferentes a Ingeniería Electrónica. [Perception study on teaching methodologies of electronics topics in programs other than Electronic Engineering]. Rev. Educ. En Ing. 2009, 8, 93-101.

27. Burgess, M.L.; Ice, P. Optimal experience in virtual environments among college level developmental readers. J. Educ. Comput. Res. 2001, 44, 429-451. [CrossRef]

28. Parneet, P. Virtual Placements to Develop Employability Skills for Civil and Environmental Engineering Students. Educ. Sci. 2015, 5, 47-64. [CrossRef]

29. Kim, D.; Blankenship, R.J. Using Second Life as a virtual collaborative tool for preservice teachers seeking English for speakers of other languages endorsement. J. Educ. Comput. Res. 2013, 48, 19-43. [CrossRef]

30. Dieterle, E.; Clarke, J. Multiuser virtual environments for teaching and learning. In Encyclopedia of Multimedia Technology and Networking, 2nd ed.; Pagani, M., Ed.; Idea Group, Inc.: Hershey, PA, USA, 2007.

31. Warburton, S. Second Life in higher education: Assessing the potential for and the barriers to deploying virtual worlds in learning and teaching. Br. J. Educ. Technol. 2009, 40, 414-426. [CrossRef]

32. Henderson, M.; Huang, H.; Grant, S.; Henderson, L. Language Acquisition in Second Life: Improving Self-Efficacy Beliefs. In Same Places, Different Spaces. Proceedings Ascilite Auckland 2009. Available online: http://www.ascilite.org.au/conferences/auckland09/procs/henderson.pdf (accessed on 25 August 2018).

33. Aguilar, F.J.; Lucas, M.; Aguilar, M.A.; Reca, J.; Luque, A.; Cardona, A.; Carrión, J.J. 3D Immersive Evironments in Higher Education Blearning Implementations. Preliminary Results. In Research in Interactive Design; Fischer, X., Daidie, A., Eynard, B., Paredes, M., Eds.; Springer: Basel, Switzerland, 2016; Volume 4, pp. 624-628.

34. González-Yebra, Ó.; Aguilar, M.A.; Aguilar, F.J.; Lucas, M. Evaluación de entornos inmersivos 3D como herramienta de aprendizaje B-Learning. [Evaluation of 3D immersive environments in B-Learning implementations]. Educación XX1 2018, 21, 417-440. [CrossRef]

35. Lee, Y. Design participation tactics: The challenges and new roles for designers in the co-design process. Codesign Int. J. Cocreation Des. Arts 2008, 4, 31-50. [CrossRef]

36. Sanders, E.B.N.; Stappers, P.J. Co-creation and the new landscape of design. Codesign: Int. J. Cocreation Des. Arts 2008, 4, 5-18. [CrossRef]

37. Rouibah, K.; Caskey, K. A workflow system for the management of inter-company collaborative engineering processes. J. Eng. Des. 2003, 14, 273-293. [CrossRef]

38. Ostergaard, K.J.; Summers, J.D. Development of a systematic classification and taxonomy of collaborative design activities. J. Eng. Des. 2009, 20, 57-81. [CrossRef]

39. Kano, N.; Seraku, N.; Takahashi, F.; Tsuji, S. Attractive Quality and Must-Be Quality. J. Jpn. Soc. Qual. Control 1984, 14, 39-48.

40. Stockman, C. Decoding Technology Acceptance in Education; Routledge: London, UK, 2018.

41. Gill, J.; Johnson, P. Research Methods for Managers, 2nd ed.; SAGE Publications: London, UK, 2010.

42. Lee, N.; Lings, I. Doing Business Research. A Guide to Theory and Practice; SAGE Publications: London, UK, 2008. 
43. Teddlie, C.; Tashakkori, A. Mixed methods: Contemporary issues in an emerging field. In Handbook of Qualitative Research, 4th ed.; Denzin, N.K., Lincoln, Y.S., Eds.; Sage: Thousand Oaks, CA, USA, 2011; pp. 285-299.

44. Cuestionario Experiencia Modelo de Kano [Experience Questionnaire Kano Model]. Available online: https:/ / goo.gl/fYKXEN (accessed on 17 January 2019).

45. Holness, G.V.R. Building information modeling gaining momentum. Ashrae J. 2008, 50, $28-40$.

46. OpenSimulator. Available online: http:/ / opensimulator.org/wiki/Main_Page (accessed on 17 January 2019).

47. Berger, C.; Blauth, R.; Boger, D.; Bolster, C.; Burchill, G.; DuMouchel, W.; Walden, D. Kano's Methods for Understanding Customer-defined Quality. Cent. Qual. Manag. J. 1993, 2, 3-36.

48. Tontini, G. Integrating the Kano Model and QFD for Designing New Products. Total Qual. Manag. Bus. 2007, 18, 599-612. [CrossRef]

49. Bowers, K.W.; Ragas, M.W.; Neely, J.C. Assessing the value of virtual worlds for post-secondary instructors: A survey of innovators, early adopters and the early majority in Second Life. Int. J. Hum. Soc. Sci. Res. 2009, 3, 40-50.

50. Beltrán Sierra, L.M.; Gutiérrez, R.S.; Garzón-Castro, C.L. Second Life as a support element for learning electronic related subjects: A real case. Comput. Educ. 2012, 58, 291-302. [CrossRef]

51. Patterson, P.G.; Spreng, R.A. Modeling the relationship between perceived value, satisfaction and repurchase intentions in a business-to-business, services context: An empirical examination. Int. J. Serv. Ind. Manag. 1997, 8, 414-434. [CrossRef]

52. Van Riel, A.C.R.; Liljander, V.; Jurriëns, P. Exploring consumer evaluations of e-services: A portal site. Int. J. Serv. Ind. Manag. 2001, 12, 359-377. [CrossRef]

53. Chen, L.H.; Kuo, Y.F. Understanding e-learning service quality of a commercial bank by using Kano's model. Total Qual. Manag. Bus. 2011, 22, 99-116. [CrossRef]

54. González-Yebra, Ó.; Aguilar, M.A.; Aguilar, F.J.; Lucas, M. Entornos inmersivos 3D en la enseñanza a distancia: Estudio para su implementación a partir de un método de desarrollo de productos. 3D immersive environments in distance education: Study for its implementation based on a product development method]. In Desafíos del Paradigma Educativo en el Siglo XXI: Investigación, Innovación y Formación; Filgueira-Arias, C., Ed.; Global Knowledge Academics: Madrid, Spain, 2017; pp. 169-174, ISBN 978-84-15665-17-5.

55. Matzler, K.; Hinterhuber, H.H.; Bailom, F.; Sauerwein, E. How to delight your customers. J. Prod. Brand Manag. 1996, 5, 6-18. [CrossRef]

56. Dede, C. The evolution of constructivist learning environments: Immersion in distributed virtual worlds. Educ. Technol. 1995, 35, 46-52.

57. Pellas, N.; Peroutseas, E. Gaming in Second Life via Scratch4SL: Engaging High School Students in Programming Courses. J. Educ. Comput. Res. 2016, 54, 108-143. [CrossRef]

58. Newman, T.; Beetham, H. Student Digital Experience Tracker 2017: The Voice of 22,000 Learners; JISC: London, UK, 2017.

59. Mayrath, M.C.; Traphagan, T.; Jarmon, L.; Trivedi, A.; Resta, P. Teaching with virtual worlds: Factors to consider for instructional use of second life. J. Educ. Comput. Res. 2010, 43, 403-444. [CrossRef]

60. Cheng, G. Exploring Students' Learning Styles in Relation to Their Acceptance and Attitudes Towards Using Second Life in Education: A Case Study in Hong Kong. Comput. Educ. 2014, 70, 105-115. [CrossRef]

61. González-Yebra, Ó.; Aguilar, M.A.; Aguilar, F.J. Is the design a vector to be considered in the agri-food industry? An interprofessional analysis in Andalusia (Spain). In Advances on Mechanics, Design Engineering and Manufacturing II; Springer: Berlin, Germany, 2019.

62. Tassinary, L.G.; Cacioppo, J.T. Unobservable facial actions and emotion. Psychol. Sci. 1992, 3, 28-33. [CrossRef]

63. Norman, D.A. Emotional Design: Why We Love (or Hate) Everyday Things; Basic Books: New York, NY, USA, 2004.

(C) 2019 by the authors. Licensee MDPI, Basel, Switzerland. This article is an open access article distributed under the terms and conditions of the Creative Commons Attribution (CC BY) license (http:/ / creativecommons.org/licenses/by/4.0/). 